\title{
ELUCIDATION OF THE PHAGOCYTOSIS MECHANISM WITH THE AID OF LUMINOUS BACTERIA
}

\author{
Mira BaraK, S. Ulitzur* and D. Merzbach \\ Department of Microbiology, Technion Faculty of Medicine and Rambam Medical \\ Center, and $*$ Department of Food Engineering and Biotechnology, Technion-Israel \\ Institute of Technology, Haifa, Israel
}

\begin{abstract}
Summary. Phagocytosis of the luminous bacterium Vibrio cholerae var. albensis caused a similar decrease both in viable count and in the in-vivo luminescence. These effects of polymorphonuclear neutrophil leukocytes (PMN) were oxygen-dependent processes. Exposure of PMN to oxygen caused a prompt decrease in the luminescence of bacteria that had been ingested in anaerobic conditions. Cell-free supernates from active PMN suspensions caused a decrease in luminescence and as much as $10 \%$ of the killing could be attributed to extracellular killing. Similarly, bacteria entrapped on a membrane filter showed a decrease in luminescence upon addition of active PMN, even though they could not be ingested.
\end{abstract}

\section{INTRODUCTION}

Phagocytosis of bacteria by leukocytes is accompanied by a burst of non-mitochondrial respiration. Although this oxygen consumption is not required for phagocytosis (Koch, 1978), it is required for the killing of certain bacteria (Iyer, Islam and Quastel, 1961; McRipley and Sbarra, 1967; Mandell, 1974; Curnutte and Babior, 1975; Ingham et al., 1981). In addition, cells from patients with the rare congenital syndrome of chronic granulomatous disease do not show any evidence of the respiratory burst (Holmes, Page and Good, 1967) and kill bacteria less efficiently than do normal cells (Quie et al., 1967; Segal et al., 1982).

The efficient microbicidal activity of the polymorphonuclear leukocyte (PMN) depends upon the formation of highly reactive products of oxygen metabolism such as superoxide $\left(\mathrm{O}_{2}{ }^{-}\right)$, hydrogen peroxide, singlet oxygen $\left(\mathrm{O}_{2}{ }^{\prime}\right)$ and the hydroxyl radical (Babior, 1978; Klebanoff, 1980). The mechanism of activation of the bactericidal system has not been elucidated, and it is not clear whether the bacteria are killed extracellularly and then ingested or the killing is an intracellular process.

The bacterial luminescence system offers a unique model to study the interaction between the phagocyte and bacteria. The luminescence level reflects both the cellular metabolic activity and the viability of the phagocytosed bacteria (Barak, Ulitzur and Merzbach, $1983 a$ and $b$ ). The bioluminescence test for phagocytosis is simple, rapid and non-destructive to the experimental system and, therefore, allows a continuous 
determination of the kinetics of the process (Barak et al., 1983b). The luminous bacterium Vibrio cholerae var. albensis resembles the pathogenic $V$. cholerae strains (Bauman et al., 1980; Blake, Weave and Hollis, 1980) and thus represents a realistic model for phagocytosis. The present communication shows the important role of oxygen in the PMN bactericidal mechanism and presents evidence for and an estimation of the extent of extracellular killing.

\section{MATERIALS AND METHODS}

Bacteria. $V$. cholerae var. albensis was grown in nutrient broth (Difco Laboratories, Detroit, MI) containing $\mathrm{NaCl} 1 \%(\mathrm{w} / \mathrm{v}), \mathrm{KCl} 0 \cdot 1 \%$ (w/v) and $\mathrm{MgSO}_{4} \cdot 7 \mathrm{H}_{2} \mathrm{O} 0 \cdot 4 \%$ (w/v) (NBC;

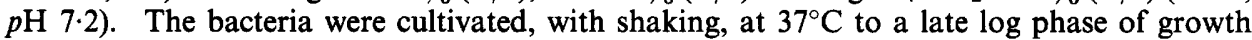
showing a turbidity of 180 Klett-Summerson units (filter 66) and a luminescence of $2 \times 10^{11}$ quanta $/ \mathrm{s} / \mathrm{ml}$. Cells were washed by centrifugation at $10000 \mathrm{~g}$ for $10 \mathrm{~min}$ at $4^{\circ} \mathrm{C}$ and suspended in phosphate-buffered saline (PBS; $\mathrm{NaCl} \mathrm{0.8 \%} \mathrm{w/v} \mathrm{K} \mathrm{K}_{2} \mathrm{HPO}_{4} 0.12 \% \mathrm{w} / \mathrm{v}, \mathrm{KH}_{2} \mathrm{PO}_{4} 0.034 \% \mathrm{w} / \mathrm{v}$; $p \mathrm{H} 7 \cdot 3$ ), containing $\mathrm{CaCl}_{2} 0 \cdot 17 \% \mathrm{w} / \mathrm{v}, \mathrm{MgSO}_{4} 0.05 \% \mathrm{w} / \mathrm{v}$, bovine serum albumin $0 \cdot 1 \% \mathrm{w} / \mathrm{v}(\mathrm{BSA}$; Sigma Chemical Co., St Louis, MO) and glucose $0 \cdot 18 \% \mathrm{w} / \mathrm{v}$. This buffer was designated PBSC. Viable counts were made in duplicate, after an appropriate dilution in saline by plating on NBC agar (NBC solidified with $1 \% \mathrm{w} / \mathrm{v}$ agar; Difco). The colonies were counted after incubation for $24 \mathrm{~h}$ at $37^{\circ} \mathrm{C}$.

Human serum was a pool from several healthy donors. Sera were separated from blood, clotted for $1 \mathrm{~h}$ at room temperature, by centrifugation at $2500 \mathrm{~g}$ for $15 \mathrm{~min}$ and stored at $-20^{\circ} \mathrm{C}$ in $1.5-\mathrm{ml}$ volumes until required.

Polymorphonuclear leukocytes were obtained from $60 \mathrm{ml}$ of heparinised blood taken from three healthy donors. Red cells were removed by sedimentation with dextran $6 \% \mathrm{w} / \mathrm{v}$ and leukocytes separated on a Ficoll-Hypaque gradient as described by Ferrante and Thong (1978). Cell viability checked by trypan blue exclusion was $>95 \%$.

Opsonisation procedure. Bacteria $\left(10^{8}\right.$ cells $\left./ \mathrm{ml}\right)$ were opsonised in serum $5 \% \mathrm{v} / \mathrm{v}$ in PBSC for $30 \mathrm{~min}$ at $30^{\circ} \mathrm{C}$ and washed twice by centrifugation in PBSC.

Phagocytosis assay. The opsonised bacteria and the PMN were added to the PBSC buffer at different concentrations (the usual ratio of PMN to bacteria was $2: 1$ ) in a final test volume of 1 $\mathrm{ml}$ in a clean scintillation vial. The vials were shaken gently at $37^{\circ} \mathrm{C}$, and the bioluminescence was determined periodically. For viable counts, $0 \cdot 1-\mathrm{ml}$ amounts were diluted in PBSC containing Triton X-100 $0.1 \% \mathrm{v} / \mathrm{v}$, vortex mixed to disrupt the PMN and plated as described above. Tests with entrapped bacteria were performed after $2 \times 10^{6}$ bacteria contained in 1-ml volumes were entrapped on 3- $\mu \mathrm{m}$ membrane filters (Schleicher and Schull, $25 \mathrm{~mm}$ diameter) by filtration under vacuum followed by three washings with $5 \mathrm{ml}$ of PBSC.

Anaerobic phagocytosis assay. Opsonised bacteria were added to pre-boiled PBSC containing dithionite (Sigma) $100 \mu \mathrm{g} / \mathrm{ml}$ and vials were sealed hermetically, as described by Levi and Ulitzur (1983). Each vial was tested for anaerobiosis before and after injection of PMN by determining its in-vivo luminescence by a scintillation counter. Any vial that showed detectable light was rejected. At different intervals, vials with or without PMN were exposed to air; samples of $1 \mathrm{ml}$ were removed, and their luminescence was determined. At the same sampling times 2-ml samples were centrifuged at $150 \mathrm{~g}$ for $10 \mathrm{~min}$ at $4^{\circ} \mathrm{C}$. The supernates were removed and diluted for viable counts. The sediments were suspended in $1 \mathrm{ml}$ of PBSC containing Triton $\mathrm{X}-1000 \cdot 1 \% \mathrm{v} / \mathrm{v}$; the PMN were disrupted by vortex agitation, and the sample diluted for viable counts.

Bioluminescence was determined in a scintillation counter (Packard, Model 2001) operating without coincidence at the ${ }^{3} \mathrm{H}$ setting at $30^{\circ} \mathrm{C}$. When the luminescence level was above $10^{5}$ quanta/s, a sensitive photometer photomultiplier calibrated by the Hastings and Weber (1963) standard was used.

\section{RESUltS}

The effect of PMN on the potential luminescence and viability of $V$. cholerae cells 


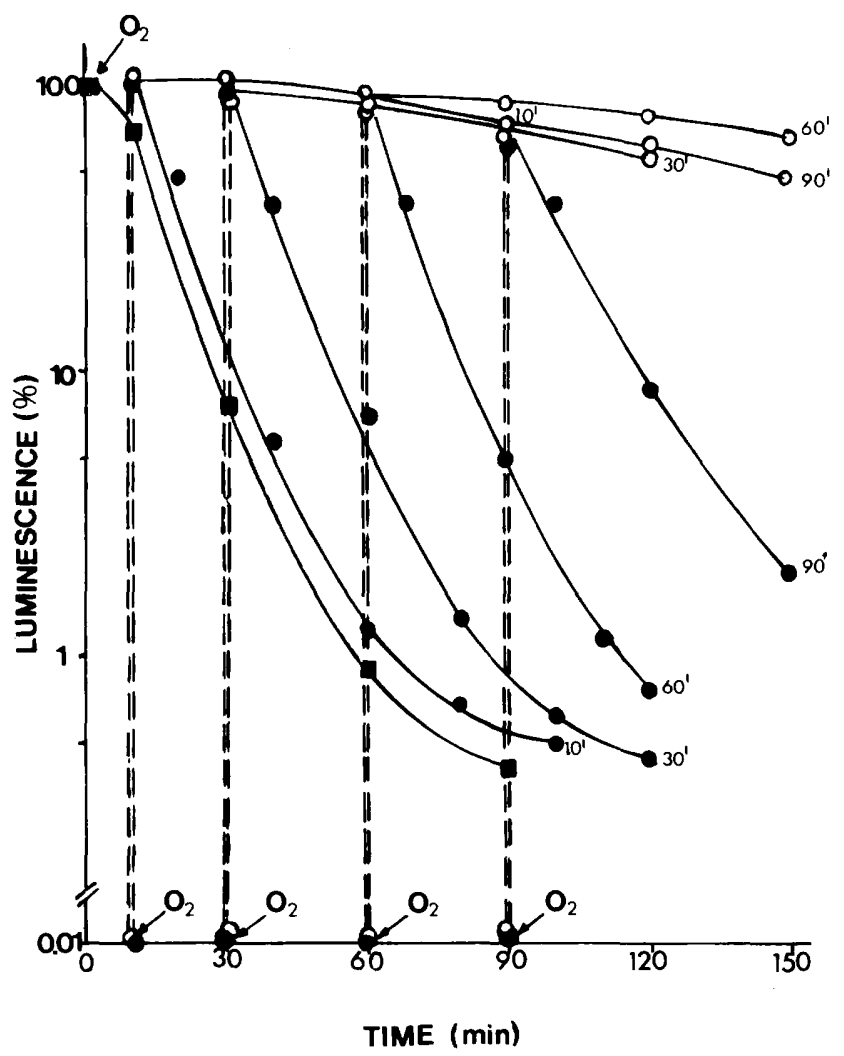

FIG. 1.-The effect of exposure to oxygen on luminescence, after different periods of anaerobic phagocytosis. Opsonised bacteria $\left(5 \times 10^{6} \mathrm{cells} / \mathrm{ml}\right)$ were added to boiled PBSC containing dithionite $100 \mu \mathrm{g} / \mathrm{ml}$. The vials were closed hermetically, and $10^{7} \mathrm{PMN} / \mathrm{ml}$ were injected. At different intervals of anaerobic phagocytosis, vials with PMN (solid symbols) or without PMN (open symbols) were exposed to air (as indicated by arrows), and the luminescence was determined for $60-90 \mathrm{~min}$. Standard test: $=$ aerobic decrease in luminescence.

that were incubated in anaerobic conditions is shown in figs. 1 and 2 , respectively. Neither the luminescence nor the viability was affected by the PMN in anaerobic conditions. The exposure to air after different periods of anaerobic phagocytosis resulted in a prompt burst of luminescence, followed by a rapid decrease in the emitted light. This drop in luminescence occurred only in the presence of PMN; in their absence, the light emission remained high and steady throughout the experiment.

Microscopic examination revealed that after $1 \mathrm{~h}$ most of the bacteria had been ingested during the anaerobic phase. This observation was further strengthened by the fact that most of the bacteria disappeared from the supernate of both the anaerobic and the aerobic assay systems (fig. 2). However, while the anaerobically-phagocytised bacteria accumulated within the PMN, the aerobically-phagocytised bacteria disappeared with time. It should be noted that the method employed for achieving anaerobiosis by addition of dithionite $100 \mu \mathrm{g} / \mathrm{ml}$ did not interfere with the potential of PMN to act in aerobic conditions.

As we have already shown (Barak et al., 1983b), the fall in the luminescence of $V$. cholerae cells upon the addition of PMN in aerobic conditions began after only a short 

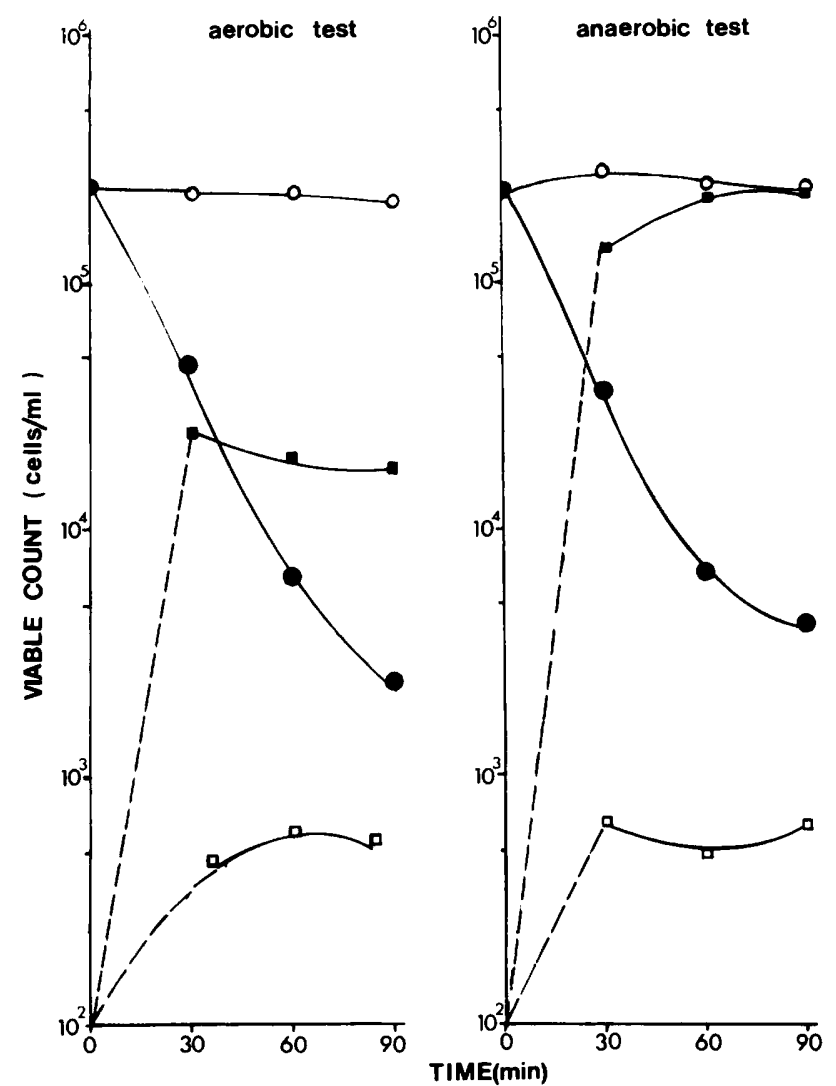

FIG. 2.-Viability of bacteria during aerobic and anaerobic phagocytosis. Opsonised bacteria $\left(2.3 \times 10^{5}\right.$ cells $/ \mathrm{ml}$ ) were incubated aerobically or anaerobically, as in fig. 1 , with $10^{6} \mathrm{PMN} / \mathrm{ml}$. After incubation for 30,60 or $90 \mathrm{~min}, 2-\mathrm{ml}$ samples were centrifuged at $150 \mathrm{~g}$ for $10 \mathrm{~min}$ at $4^{\circ} \mathrm{C}$ and the supernate $(\bullet-$ or $O-O)$ and sediment $(\square-\square$ or $\square-\square)$ sampled for viable counts. Open symbols represent controls without PMN and solid symbols represent test mixtures with PMN.

time lag that was required for the adherence and engulfment process. This pre-ingestion stage did not require the presence of oxygen. Upon shifting from anaerobic to aerobic conditions, the PMN killing apparatus was immediately potentiated, as could be judged from the prompt decrease in luminescence (fig. 1). Using the data of fig. 2, the extent of the intracellular and extracellular killing of bacteria in the phagocytosis process was estimated. The table shows that a difference of $8-10 \%$ existed between the intracellular and the total killing of the bacteria in the phagocytosis assay.

In order to obtain a more direct estimation of the extracellular killing, we performed the following experiments: $V$. cholerae cells were filtered through a 3- $\mu \mathrm{m}$ membrane filter, and the non-entrapped bacteria were washed out by repeated washings; the entrapped bacteria could not be engulfed because they were trapped in the filter. Fig. 3 shows that $c .60 \%$ decrease in luminescence occurred when such filter-bound bacteria were incubated with PMN for $30 \mathrm{~min}$. This decrease in luminescence could not be accounted for by bacteria that escaped from the filter, 


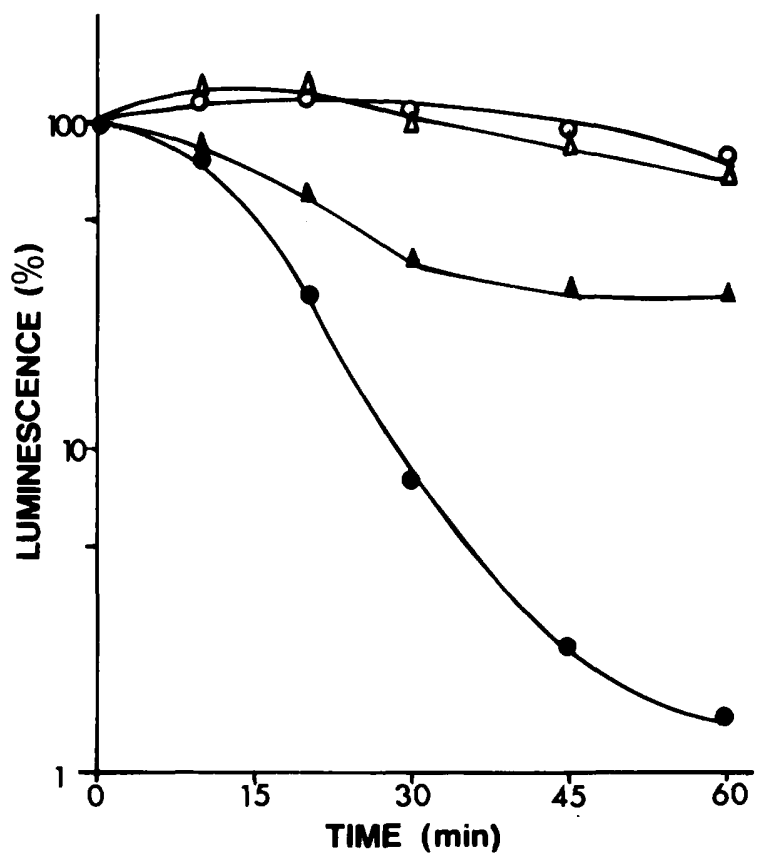

FIG. 3.-Decrease in luminescence of entrapped bacteria incubated with PMN. Opsonised bacteria $\left(10^{6}\right)$ were trapped on 3- $\mu \mathrm{m}$ membrane filters by filtration under vacuum. The filters were placed in vials containing $2 \times 10^{\circ}$ PMN in $1 \mathrm{ml}$ of PBSC ( $\left.\triangle-\triangle\right)$. The standard test consisted of $10^{\circ}$ opsonised bacteria in $1 \mathrm{ml}$ of PBSC containing $2 \times 10^{6} \mathrm{PMN}(\bullet)$. Open symbols represent bacteria without PMN, either free $(\mathrm{O}-\mathrm{O})$ or entrapped on the filter $\left(\Delta \frac{\Delta}{20}\right)$. The vials were incubated with shaking at $37^{\circ} \mathrm{C}$, and the luminescence was determined at $0,10,20,30,45$ and $60 \mathrm{~min}$.

because only $0.08 \%$ of the bacteria were released from the filter during incubation for $1 \mathrm{~h}$ in the absence of PMN (data not shown). Fig. 4 shows that supernates from active PMN were able to reduce the luminescence of opsonised bacteria. It can be seen that the effect of the supernate was proportional to the length of the previous phagocytosis period.

\section{Discussion}

The effect of anaerobiosis on phagocytosis by PMN has been studied in detail (Selvaraj and Sbarra, 1966; McRipley and Sbarra, 1967; Mandell, 1974; Ingham et al., 1981) but the conclusions of these studies do not agree with each other. While some authors showed that anaerobiosis interfered with the intracellular killing of Escherichia coli (Selvaraj and Sbarra, 1966), Pseudomonas aeruginosa and Staphylococcus albus (McRipley and Sbarra, 1967), other investigators claimed that other species were killed by PMN in anaerobic conditions (Mandell, 1974). Ingham et al. (1981) showed that only dilute bacterial suspensions $\left(\leqq 10^{7}\right.$ cells $\left./ \mathrm{ml}\right)$ were killed in anaerobic conditions and that anaerobic bacteria interfered with the killing of the aerobic ones by depleting the serum of essential opsonic factors. The discrepancy between these results can be explained by the different techniques employed and by different susceptibilities of bacterial genera to the oxygen-dependent bactericidal mechanism. The methods employed for achieving anaerobiosis (Mandell, 1974; Ingham et al., 


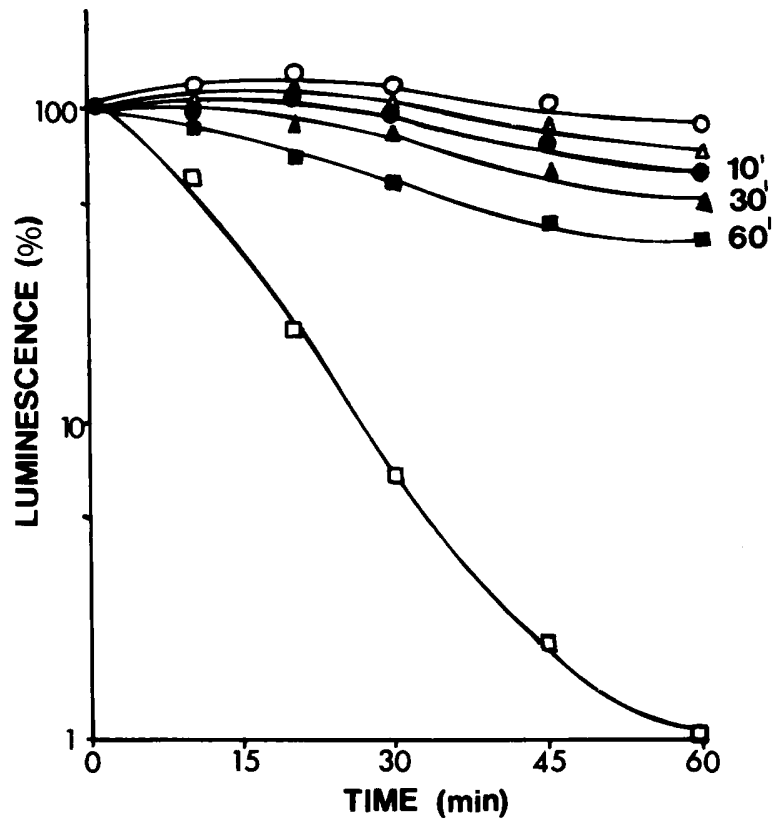

FIG. 4.-Effect of supernates from phagocytosis assays on luminescence of $\boldsymbol{V}$. cholerae. The aerobic phagocytosis assays were performed as described in the legend to fig. 1 (standard test: $\square-\square$ ). At intervals of 10,30 and $60 \mathrm{~min}$ (solid symbols), 2-ml samples were centrifuged for $10 \mathrm{~min}$ at $10000 \mathrm{~g}$ at $4^{\circ} \mathrm{C}$, and $1 \mathrm{ml}$ of the supernate was added to $10^{\circ}$ luminous bacteria. Supernate from PMN incubated alone for $60 \mathrm{~min}(\Delta-\Delta)$ was the control; $\mathrm{O}-\mathrm{O}=$ bacteria alone. The vials were incubated with shaking at $37^{\circ} \mathrm{C}$ and the luminescence was determined at $0,10,20,30,45$ and $60 \mathrm{~min}$.

TABLE

Comparison of intracellular and total bacterial killing

\begin{tabular}{|c|c|c|c|c|}
\hline $\begin{array}{l}\text { Time } \\
(\min )\end{array}$ & $\begin{array}{l}\text { Number of bacteria } \\
\text { in aerobic PMN }(\mathrm{X}) \\
\left(\times 10^{4}\right)\end{array}$ & $\begin{array}{l}\text { Number of bacteria } \\
\text { in anaerobic PMN }(\mathrm{Y}) \\
\left(\times 10^{5}\right)\end{array}$ & $\begin{array}{l}\text { Intracellular } \\
\text { killing }(\mathrm{Z})^{*} \\
(\%)\end{array}$ & $\begin{array}{c}\text { Decrease in } \\
\text { viable count } \\
\text { (direct test) } \\
(\%)\end{array}$ \\
\hline $\begin{array}{l}30 \\
60 \\
90\end{array}$ & $\begin{array}{l}2.5 \\
2.0 \\
1.9\end{array}$ & $\begin{array}{l}1 \cdot 4 \\
2 \cdot 2 \\
2 \cdot 3\end{array}$ & $\begin{array}{l}82 \cdot 14 \\
90 \cdot 91 \\
91 \cdot 74\end{array}$ & $\begin{array}{l}92 \cdot 50 \\
99 \cdot 00 \\
99 \cdot 63\end{array}$ \\
\hline
\end{tabular}

$* \mathrm{Z}=(\mathrm{Y}-\mathrm{X}) / \mathrm{Y} \times 100$

1981), such as nitrogen washout or the use of the anaerobic jar, cannot provide the strict anaerobic environment that was obtained with the use of dithionite. The pre-opsonisation procedure that was employed in the present study further improved the test by eliminating the possibility of improper opsonisation during the anaerobic period.

The technique that we have described has the advantage of being a non-destructive test in which the presence of even trace amounts of $\mathrm{O}_{2}$ in the system can be detected continuously. Luminous bacteria emit light at $\mathrm{O}_{2}$ concentrations as low as $10^{-8} \mathrm{M}$ 
(Oshino et al., 1972). The shift from anaerobiosis to aerobiosis revealed instantly the degree of bacterial killing and allowed determination of the oxygen-dependent killing. The killing of the luminous bacteria almost exclusively in aerobic conditions is obvious if we consider their high susceptibility to oxygen-derived metabolites with regard to viability (Barak et al., 1983b) and mutagenesis (Barak et al., 1983a).

With the aid of immobilised luminous bacteria we were also able to evaluate directly the extent of extracellular killing of bacteria during phagocytosis. Other authors (Koch, 1978; Gabig and Babior, 1981) could not assess extracellular killing by employing the direct bactericidal test. The experiments performed to assess the extracellular killing showed that there was almost no further decrease in luminescence after the first $30 \mathrm{~min}$ of the test. The factor(s) responsible for this phenomenon must be investigated further.

\section{REFERENCES}

Babior B M 1978 Oxygen-dependent microbial killing by phagocytes. New England Journal of Medicine 298:659-668, 721-725.

Barak M, Ulitzur S, Merzbach D 1983a Phagocytosis-induced mutagenesis in bacteria. Mutation Research 121:7-16.

Barak M, Ulitzur S, Merzbach D $1983 b$ The use of luminous bacteria for determination of phagocytosis. Journal of Immunological Methods 64:353-363.

Baumann P, Baumann L, Bang S S, Woolkalis M J 1980 Re-evaluation of the taxonomy of Vibrio, Beneckea and Photobacterium: abolition of the genus Beneckea. Current Microbiology 4:127-132.

Blake P A, Weaver R E, Hollis D G 1980 Diseases of human (other than cholera) caused by vibrios. Annual Review of Microbiology 34:341-367.

Curnutte J T, Babior B M 1975 Effects of anaerobiosis and inhibitors on $\mathrm{O}_{2}{ }^{-}$production by human granulocytes. Blood 45:851-861.

Ferrante A, Thong Y H 1978 A rapid one-step procedure for purification of mononuclear and polymorphonuclear leukocytes from human blood using a modification of the HypaqueFicoll technique. Journal of Immunological Methods 24:389-393.

Gabig T G, Babior B M 1981 The killing of pathogens by phagocytes. Annual Review of Medicine 32:313-326.

Hastings J W, Weber G 1963 Total quantum flux of isotropic sources. Journal of the Optical Society of America 53:1410-1415.

Holmes B, Page A R, Good R A 1967 Studies of the metabolic activity of leukocytes from patients with a genetic abnormality of phagocytic function. Journal of Clinical Investigation 46:1422-1432.

Ingham H R, Sisson P R, Middleton R L, Narang H K, Codd A A, Selkon J B 1981 Phagocytosis and killing of bacteria in aerobic and anaerobic conditions. Journal of Medical Microbiology 14:391-399.

Iyer G Y N, Islam M F, Quastel J H 1961 Biochemical aspects of phagocytosis. Nature, London 192:535-541.

Klebanoff S J 1980 Oxygen metabolism and the toxic properties of phagocytes. Annals of Internal Medicine 93:480-489.

Koch C 1978 Bactericidal activity of human neutrophil granulocytes. Studies in clinical disorders with in vitro bactericidal test. Acta Pathologica, Microbiologica, et Immunologica Scandinavica, Section C. Immunology Supplement 266:7-62.

Levi B Z, Ulitzur S 1983 Proflavin and norharman induce luciferase synthesis under anaerobiosis. Archives of Microbiology 134:261-264.

Mandell G L 1974 Bactericidal activity of aerobic and anaerobic polymorphonuclear neutrophils. Infection and Immunity 9:337-341.

McRipley R J, Sbarra A J 1967 Role of the phagocyte in host parasite interactions. XI. 
Relationship between stimulated oxidative metabolism and hydrogen peroxide formation and intracellular killing. Journal of Bacteriology 94:1417-1424.

Oshino R, Oshino N, Tamura M, Kobilinsky L, Chance B 1972 A sensitive bacterial luminescence probe for $\mathrm{O}_{2}$ in biochemical systems. Biochimica et Biophysica Acta 273:5-17.

Quie P G, White J G, Holmes B, Good R A 1967 In-vitro bactericidal capacity of human polymorphonuclear leukocytes: diminished activity in chronic granulomatous disease of childhood. Journal of Clinical Investigation 46:668-679.

Segal A W, Harper A M, Garcia R C, Merzbach D 1982 The action of cells from patients with chronic granulomatous disease on Staphylococcus aureus. Journal of Medical Microbiology 15:441-449.

Selvaraj R J, Sbarra A J 1966 Relationship of glycolytic and oxidative metabolism to particle entry and destruction in phagocytosing cells. Nature, London 211:1272-1276. 